\title{
Prolactin as a luteotrophin during late pregnancy in pigs
}

\author{
B. Szafranska* and J. E. Tilton $\dagger$ \\ Department of Animal and Range Sciences, North Dakota State University, Fargo, ND 58105, USA
}

\begin{abstract}
The effect of prolonged hyperprolactinaemia on the secretion of $\mathrm{LH}$, progesterone and oestradiol, and its relationship to the maintenance of pregnancy was examined in pigs. Twelve crossbred, pregnant gilts were injected i.m. with $1.5 \mathrm{mg}$ haloperidol $\mathrm{kg}^{-1}$ body weight $(n=6)$ or vehicle $(n=6)$ once a day from day 60 to day 66 of pregnancy. Blood samples were collected at 08:00,12:00, 16:00,20:00, 24:00 h from day 60 to day 67 and every $15 \mathrm{~min}$ for $4 \mathrm{~h}(08: 00-12: 00 \mathrm{~h})$ on days 60,63 and 66 . Plasma concentrations of prolactin were higher $(P<0.001)$ in haloperidol-treated gilts than in control gilts $(121.3 \pm$ $4.3 \mathrm{ng} \mathrm{ml}^{-1}$ and $13.6 \pm 0.4 \mathrm{ng} \mathrm{ml}^{-1}$, respectively). Hyperprolactinaemia completely inhibited the pulsatile secretion of $\mathrm{LH}$ and diminished $(P<0.001)$ basal peripheral concentrations of LH (hyperprolactinaemia, $0.3 \pm 0.04 \mathrm{ng} \mathrm{ml}^{-1}$ and control, $0.6 \pm 0.005 \mathrm{ng} \mathrm{ml}^{-1}$ ). Despite the inhibition of LH release in hyperprolactinaemic gilts, plasma concentrations of progesterone were higher $(P<0.001)$ than in the control group $(20.8 \pm 0.6$ and $12.6 \pm 0.2 \mathrm{ng} \mathrm{ml}^{-1}$, respectively). Oestradiol concentrations were not different between groups, although oestradiol tended to be higher in hyperprolactinaemic gilts than in the control group throughout the sampling period $\left(29.1 \pm 1.9\right.$ versus $23.7 \pm 1.6 \mathrm{pg} \mathrm{m}^{-1}$, respectively). Abortion did not occur in any of the gilts. These results are the first to demonstrate that induced hyperprolactinaemia during the second half of pregnancy (days 60-66) will drastically suppress the major porcine luteotrophin but not affect pregnancy maintenance in pigs. It is possible that prolactin has a more important function in the luteotrophic complex as an additional protectant associated with the regulatory mechanism of late pregnancy maintenance than was previously reported.
\end{abstract}

\section{Introduction}

The function of prolactin and the role of the dopaminergic system in the regulation of gonadotrophin secretion in the maintenance of late pregnancy in pigs is still unclear. Kraeling and Davis (1974) reported that hypophysectomy during late pregnancy terminates pregnancy in pigs, but when prolactin was administered after hypophysectomy the pregnancy was maintained (Du Mesnil du Buisson and Denamur, 1969). Moreover, the greatest increase in prolactin-receptor content occurs at about day 60 of pregnancy (Jammes et al., 1985). Prolactin stimulates progesterone synthesis in the corpora lutea by enhancing the uptake of lipoproteins and promoting the utilization of internalized cholesterol for progesterone synthesis (Rajkumar et al., 1985). In addition, prolactin may stimulate membrane receptors for LH or for lipoproteins (Murphy and Rajkumar, 1985). These results suggest the relative importance of prolactin in the maintenance of late pregnancy in pigs. Szafranska and Ziecik (1990) proposed that there is a specific mechanism of 'substitutory compensation' as a protectant for maintenance of late pregnancy. Blocking the action of prolactin (by bromocriptine administration) causes a 10-fold rise in LH from 67 to 72 days of

*Present address: University of Agriculture and Technology, Department of Animal Physiology, 10-718 Olsztyn-Kortowo, Poland.

†Correspondence.

Revised manuscript received 13 April 1993. pregnancy, indicating a strong relationship between $\mathrm{LH}$ and prolactin secretion. The resultant hypoprolactinaemia did not result in termination of pregnancy.

Hyperprolactinaemia is frequently involved in the inhibition of gonadal functions, such as in lactational anoestrus, and is commonly associated with infertility. Sortino and Wise (1989), using rat pituitary cells, reported that induction of hyperprolactinaemia in vitro decreased LH secretion. Thus, it appears that hyperprolactinaemia may suppress $\mathrm{LH}$ secretion during pregnancy, and would result in the termination of pregnancy if there is no additional, specific mechanism of protection for pregnancy.

The objective of this study was to determine the effect of induced hyperprolactinaemia (by blockade of dopamine receptors) on LH, progesterone and oestradiol secretion and how such conditions influence the maintenance of late pregnancy in pigs.

\section{Materials and Methods}

\section{Animals and blood sampling sequence}

Twelve crossbred gilts mated at second oestrus were assigned to one of two groups: hyperprolactinaemic $(n=6)$ or control $(n=6)$. An indwelling cannula was inserted into the 
jugular vein via the cephalic vein $24-48 \mathrm{~h}$ before treatment. Blood samples were collected every $15 \mathrm{~min}$ for $4 \mathrm{~h}$ (08:0012:00) and at 16:00,20:00,24:00 h on days 60,63 and 66 or five times a day $(08: 00,12: 00,16: 00,20: 00,24: 00 \mathrm{~h})$ on day 61, $62,64,65$ and 67 of pregnancy.

The plasma obtained after centrifugation $\left(1500 \mathrm{~g}, 4^{\circ} \mathrm{C}\right.$, $10 \mathrm{~min}$ ) from all experimental animals was stored at $-20^{\circ} \mathrm{C}$ until prolactin, $\mathrm{LH}$, progesterone and oestradiol concentrations were measured by radioimmunoassay. Prolactin and LH were determined in all samples. Progesterone and oestradiol were determined in samples taken at intervals of $1 \mathrm{~h}$ during the intensive bleeding periods or twice a day.

\section{Treatment}

Haloperidol was dissolved in ethanol (less than $0.05 \%$ in final dilution for injection) and the solvent was acidified by lactic acid, lightly heated until a clear solution was obtained and finally dissolved in sterile saline. Haloperidol, $1.5 \mathrm{mg} \mathrm{kg}^{-1}$ body weight in $2 \mathrm{ml}$ of vehicle $(n=6)$, was given once a day at 08:05 from day 60 until day 66 of pregnancy. Control gilts $(n=6)$ were given vehicle only at similar times.

\section{Radioimmunoassays}

Plasma concentrations of prolactin were determined by the double antibody radioimmunoassay as described by Dusza and Krzymowska (1979) with slight modifications. First antibodies from goats immunized against porcine prolactin (Research Products, Mt Prospect, IL) were used in a titre of 1:50000. Second antibodies (goat IgG antiserum, Sigma Chemical Co, St Louis, MO), anti- $\gamma$-goat from immunized donkeys, were used in a $1: 15$ dilution and incubation was extended for an additional $24 \mathrm{~h}$. Sensitivity of the assay was $0.12 \mathrm{ng} \mathrm{ml}^{-1}$. Intra- and interassay coefficients of variation were $2.6 \%$ and $8.1 \%$, respectively.

Plasma concentrations of $\mathrm{LH}$ were determined by the method of double antibody radioimmunoassay as described by Ziecik et al. (1978) with the following modifications. Primary antibodies from immunized rabbits against a conjugate of porcine LH with ovalbumin were used (B. Szafranska and A. J. Ziecik, unpublished data). The crossreactions of antiserum used with different antigens were: $0.9 \%$ for porcine $\mathrm{GH}$ and $0.7 \%$ for bovine thyroid-stimulating hormone but $0.0 \%$ for porcine $\mathrm{FSH}$, prolactin and hCG. The period of incubation with antiserum was extended from 24 to $48 \mathrm{~h}$. Sensitivity of the assay was $0.08 \mathrm{ng} \mathrm{ml}^{-1}$. Intra- and interassay coefficients of variation were $1.7 \%$ and $4.8 \%$, respectively.

Progesterone was determined by direct assay in plasma (Diagnostic Products Co., Los Angeles, CA). Sensitivity of the assay was $0.1 \mathrm{ng} \mathrm{ml}^{-1}$. Intra- and interassay coefficients of variation were $4.6 \%$ and $5.0 \%$, respectively.

Oestradiol was determined by using a standard (Hotchkiss et al. 1971) extraction method $(500 \mu \mathrm{l}$ of serum, $4 \mathrm{ml}$ of ethyl ether) with antibodies from immunized rabbits against a conjugate of 17-oestradiol-6-CMO-BSA (B. Szafranska and A. J. Ziecik, unpublished data) and with $\left[2,4,6,7-{ }^{3} \mathrm{H}\right]$ oestradiol (Du Pont NEN Products, Boston, MA) as tracer. The crossreactions of antiserum used with different antigens were: oestrone
$0.58 \%$, and less than $0.01 \%$ for $5 \alpha$-androstane-3,17-dione, androsterone, epiandrosterone and testosterone. Any crossreactions were determined with $5 \alpha$-pregnan- $3 \alpha$-ol-20 $\alpha$-one, $5 \alpha$-pregnan-3 $\beta$-ol-20-one, progesterone, 4-pregnen-20 $\alpha$-ol3-one, 4-pregnen-20 $\beta$-ol-3-one, $5 \beta$-androstane-3 $\alpha$-17 $\beta$-dione, $5 \beta$-androstane-3 $\alpha$-17 $\beta$-diol, 4 -androstan-11 $\beta$-ol-3,17-dione and $5 \alpha$-androstan-17 $\beta$-ol-3-one. This antibody has been determined to have an affinity constant by Scatchard plot of $1.0 \times 10^{10} 1$ $\mathrm{mol}^{-1}$. The antiserum was used in a titre of $1: 30000$. Recovery of oestradiol in extracted samples was $88 \%$ and the sensitivity of the assay was $10 \mathrm{pg}$ per tube. Intra- and interassay coefficients of variation were $3.5 \%$ and $5.3 \%$, respectively.

\section{Statistical analysis}

Serially collected data were compared by analysis of variance (ANOVA) to establish the overall effects of treatment. Pulse analysis was performed and estimations of the duration and amplitude of $\mathrm{LH}$ pulse frequency were determined. Pulse amplitude was characterized as the difference between the mean concentration and the peak in blood LH concentration and pulse frequency as number of pulses in a $4 \mathrm{~h}$ period. An $\mathrm{LH}$ pulse was defined and analysed as described previously by Lejeune t $a l$. (1990).

\section{Results}

Prolactin concentration increased within $15-30 \mathrm{~min}$ of haloperidol treatment and remained above $65 \mathrm{ng} \mathrm{ml}^{-1}$ during the entire treatment period (Fig. 1a). Concentration of prolactin in hyperprolactinaemic gilts (121.3 $\left.\pm 4.3 \mathrm{ng} \mathrm{ml}^{-1}\right)$ was higher $(P<0.001)$ than in the control group $\left(13.6 \pm 0.4 \mathrm{ng} \mathrm{ml}^{-1}\right)$ from the time of the initial haloperidol treatment until $24 \mathrm{~h}$ after the final treatment on day 67. Abortion did not occur in any of the gilts. Prolactin concentrations in haloperidol-treated gilts on the days of frequent sampling (days 60,63 and 66) are given (Fig. 1b).

Haloperidol treatment strongly inhibited the release of $\mathrm{LH}$ $(P<0.001)$. Pulse activity of $\mathrm{LH}$ was almost completely inhibited and peripheral LH concentrations were decreased by $50 \%$ $\left(0.3 \pm 0.04 \mathrm{ng} \mathrm{ml}^{-1}\right.$ compared with $0.6 \pm 0.05 \mathrm{ng} \mathrm{ml}^{-1}$ for control group; Fig. 2). During periods of frequent sampling, one peak of LH release was observed (Fig. 3) in hyperprolactinaemic gilts (amplitude $1.65 \mathrm{ng} \mathrm{ml}^{-1}$; duration $20 \mathrm{~min}$ ). In the control gilts more surges were observed (mean amplitude $1.93 \mathrm{ng} \mathrm{ml}^{-1}$; average duration $32.5 \mathrm{~min}$ ). On days 63 and 66 of pregnancy, peaks of $\mathrm{LH}$ release did not occur in the hyperprolactinaemic group; however, a mean of 1.33 pulses of $\mathrm{LH}$ release per period during frequent sampling occurred in the control group (amplitude $1.51 \mathrm{ng} \mathrm{ml}^{-1}$; duration $30 \mathrm{~min}$ ).

Peripheral plasma concentrations of progesterone (Fig. 4) in hyperprolactinaemic gilts were higher $(P<0.001)$ than in the control group $\left(20.8 \pm 0.6\right.$ and $12.6 \pm 0.2 \mathrm{ng} \mathrm{ml}^{-1}$, respectively) during the entire sampling period. Oestradiol concentrations (Fig. 5) were not different $(P>0.05)$ between groups. Oestradiol concentrations tended to be higher in the hyperprolactinaemic group than in the control group throughout 


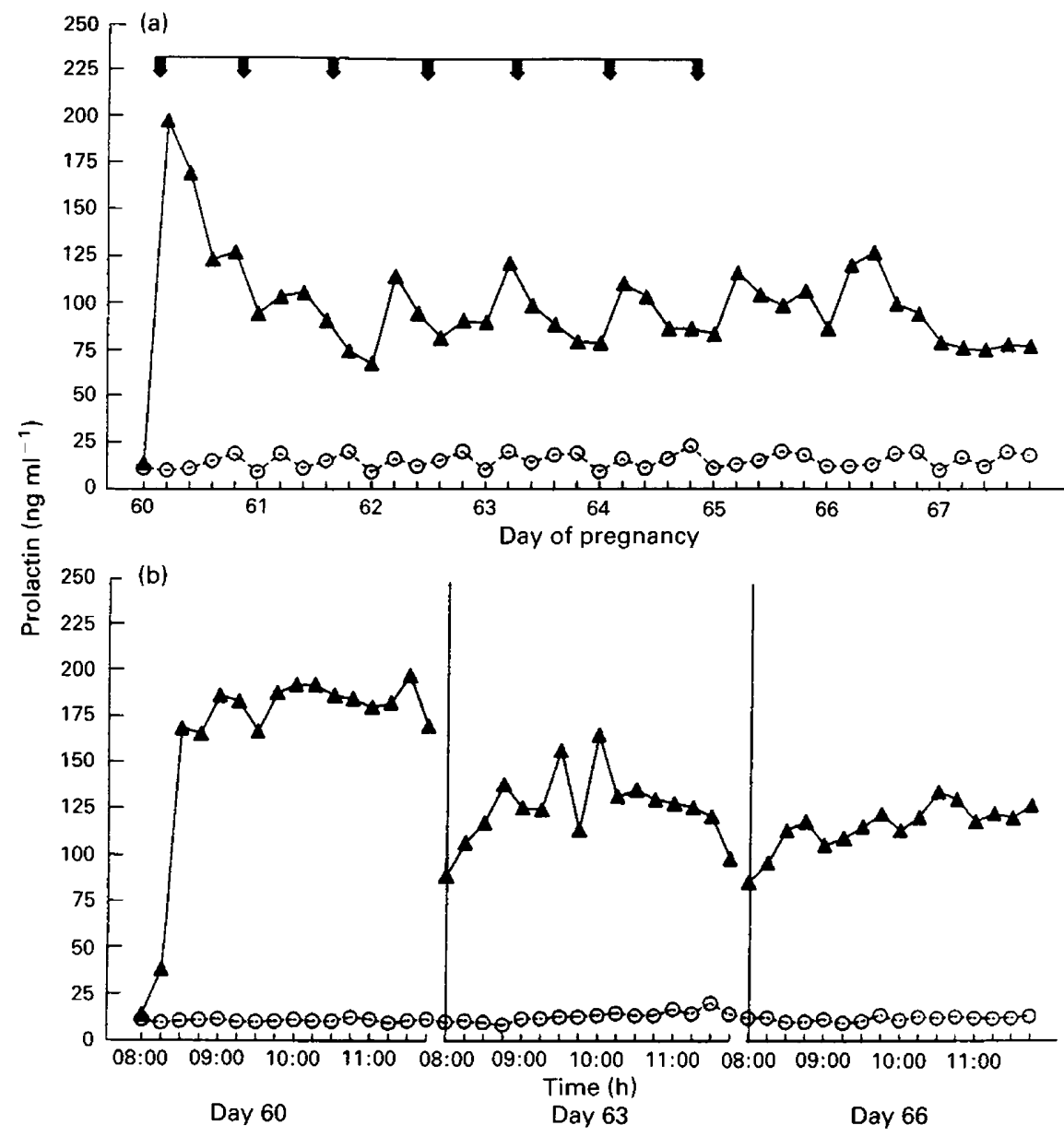

Fig. 1. Mean concentrations of prolactin $\left(\mathrm{ng} \mathrm{m}^{-1}\right)$ in haloperidol-treated $(\mathbf{A})(\mathrm{SEM}= \pm 21.5)$ and control $(O)$ (SEM $= \pm 2.0$ ) gilts $(n=6)$ : (a) from day 60 to day 67 of pregnancy, (b) during frequent sampling periods (days 60,63 and 66). Arrows indicate time of haloperidol treatment.

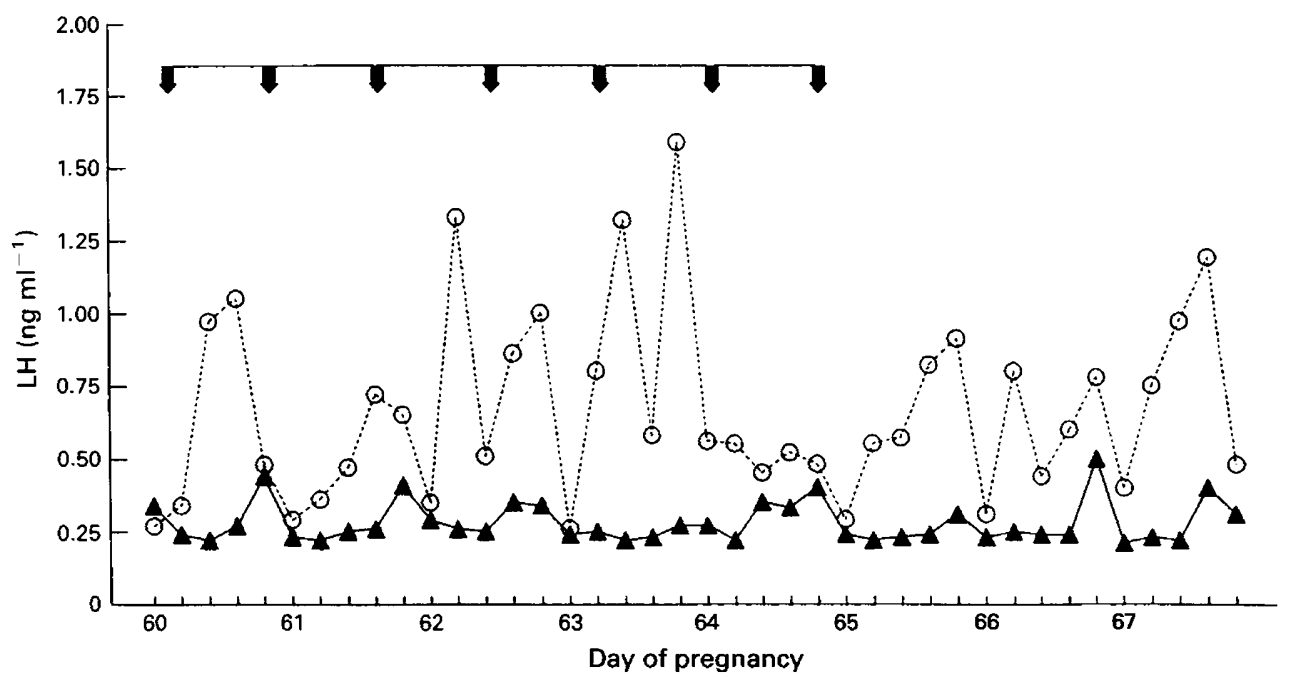

Fig. 2. Mean concentrations of $\mathrm{LH}\left(\mathrm{ng} \mathrm{ml}^{-1}\right)$ in haloperidol-treated $(\boldsymbol{\Delta})(\mathrm{SEM}= \pm 0.06)$ and control $(\mathrm{O})$ $(\mathrm{SEM}= \pm 0.21)$ gilts $(n=6)$ from day 60 to day 67 of pregnancy. Arrows indicate time of haloperidol treatment. 


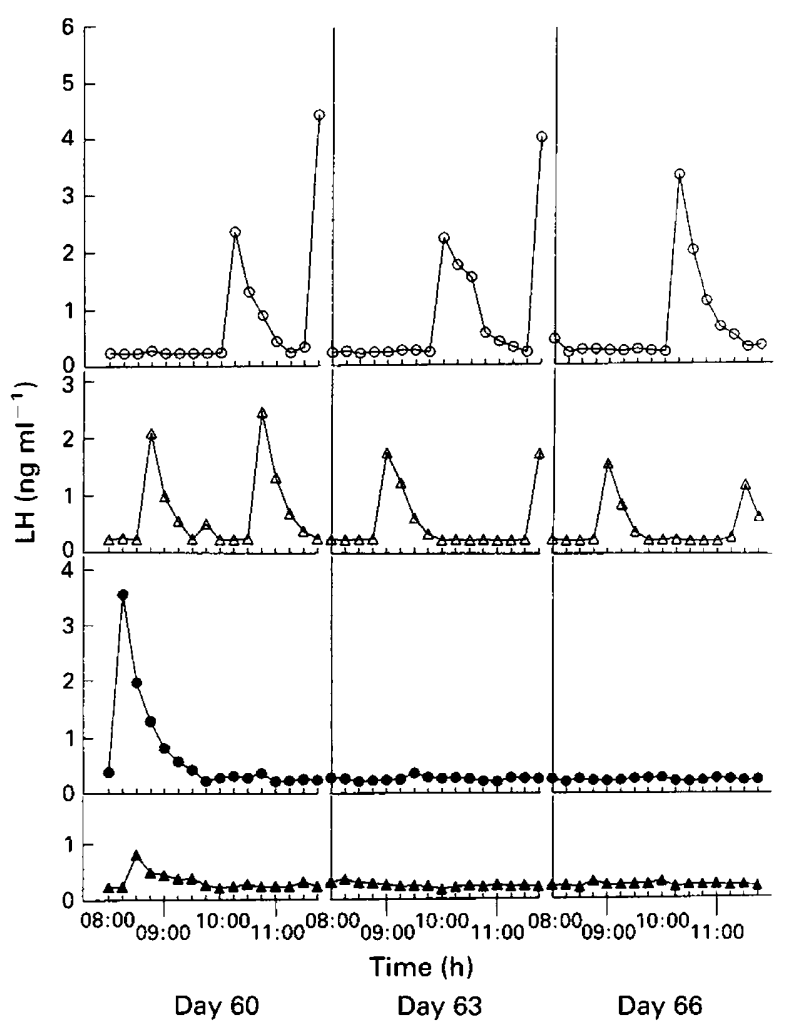

Fig. 3. Individual profiles of LH concentrations in haloperidol-treated $(\boldsymbol{\Delta}, \bigcirc)$ and control $(\triangle, O)$ pregnant gilts $(n=6)$.

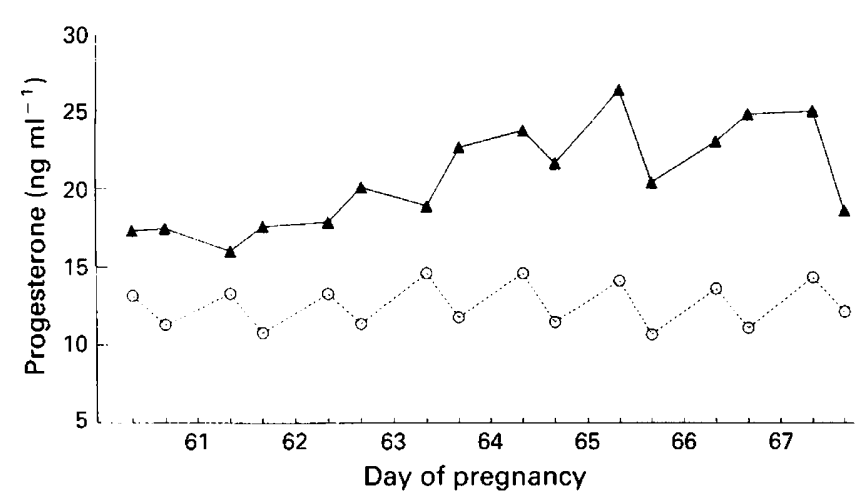

Fig. 4. Mean concentrations of progesterone $\left(\mathrm{ng} \mathrm{m}^{-1}\right)$ in haloperidoltreated $(\Delta)(\mathrm{SEM}= \pm 2.25)$ and control $(O)$ (SEM $= \pm 0.84)$ gilts $(n=6)$ from day 60 to day 67 of pregnancy.

the sampling period $\left(29.1 \pm 1.9\right.$ and $23.7 \pm 1.6 \mathrm{~g} \mathrm{ml}^{-1}$ respectively).

\section{Discussion}

This study is the first to demonstrate the effect of induced hyperprolactinaemia on maintenance of late pregnancy in pigs. The high concentrations of prolactin observed in hyperprolactinaemic gilts are usual for lactation but not for pregnancy

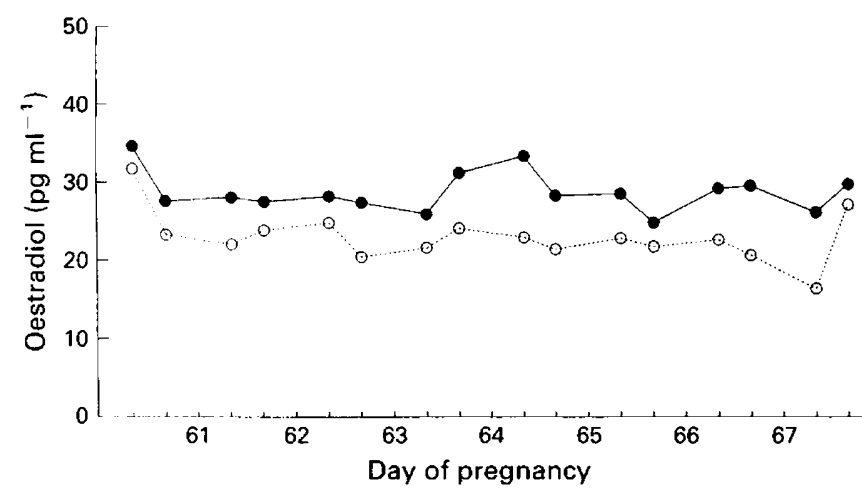

Fig. 5. Mean concentrations of oestradiol $\left(\mathrm{pg} \mathrm{m}^{-1}\right)$ in haloperidoltreated $(O)(\mathrm{SEM}= \pm 9.38)$ and control $(O)(\mathrm{SEM}= \pm 3.08)$ gilts $(n=6)$ from day 60 to day 67 of pregnancy.

and were observed to inhibit $\mathrm{LH}$ release during days $60-67$ of pregnancy. Dopamine is known to inhibit prolactin: high concentrations of dopamine are present in portal blood and DA receptors (D1 and D2) are found in the anterior and intermediate lobe of the pituitary. The dopamine pathways via tuberoinfundibular dopamine and tuberohypophysial dopamine neurones are involved in regulation of prolactin release (Benker et al., 1990; Ben-Jonathan et al, 1989). Administration of haloperidol, an antagonist of D1 and D2 receptors, blocks the presynaptic and post-synaptic receptors (Imazu et al., 1989).

Induced hyperprolactinaemia decreases the number of rat pituitary cells secreting $\mathrm{LH}$ as indicated by the reverse haemolytic plaque assay (Sortino and Wise, 1989). Prolactin may also inhibit LH release via a central action, probably via prolactindopamine and dopamine-gonadotrophin interactions. However, the mechanism of direct interaction between gonadotrophs releasing LH and prolactin by intracellular communication or indirectly between the hypophyseal connection of neurone terminals secreting $\mathrm{GnRH}$ and dopamine during late pregnancy in pigs is not completely understood. Induced hypoprolactinaemia does not cause abortion (Szafranska and Ziecik, 1990), despite a tenfold rise in LH concentration occurring from day 67 to day 72 of pregnancy suggesting a specific mechanism of 'substitutory compensation' between LH and prolactin for late pregnancy protection. In this earlier study, it was hypothesized that the inhibition of prolactin by dopaminergic bromocriptine probably affected the GnRH-dependent secretion of $\mathrm{LH}$ at the hypothalamic level. Gonadotrophin-releasing-hormone-associated-peptide (GAP) and GnRH are found in the secretory granules of nerve terminals from the rat median eminence (Ben-Jonathan et al., 1989). Nevertheless, it has been reported that GAP suppresses the release of prolactin from cultured rat anterior pituitary cells (Vacher et al., 1991), whereas active immunization against GAP increases the concentration of prolactin in serum (Nikolics et al., 1985). These reports have shown only contrasting relationships between prolactin and LH release. However, hyperprolactinaemia in rats increased the turnover of dopamine in the medial basal hypothalamus, decreasing the concentration of $\mathrm{GnRH}$ in plasma of hypophysial portal blood (Koike et al., 1991).

Despite the lower concentrations of LH observed in hyperprolactinaemic gilts, plasma progesterone concentrations were higher $(P<0.001)$ in this group. Du Mesnil du Buisson and Denamur (1969) suggested that the corpora lutea of pigs in late 
pregnancy requires prolactin for its maintenance. Yangfan et al. (1989) confirmed that prolactin is luteotrophic for ageing corpora lutea in pigs, preventing luteal regression immediately after hypophysectomy. The results reported here are supported by findings of Grinwich et al. (1983), who demonstrated in vitro that short-term incubation of prolactin-treated luteal cells from pregnant pigs killed between days 70 and 85 of pregnancy resulted in an increased progesterone accumulation in the media. Prolactin stimulation of progesterone secretion has been recognized as 'dose dependent' in humans and other species (see Murphy and Rajkumar, 1985). In addition, Wiest et al. (1968) suggested that prolactin suppresses the enzymatic degradation of progesterone to its metabolite, 20- $\alpha$-pregn-4-ene-3-one. However, Jones et al. (1983) demonstrated that prolactin induces the synthesis of progesterone as well as that of its precursor, pregnenolone. Rajkumar et al. (1984) indicated that prolactin enhances progesterone accumulation by luteal cells induced by high and low density lipoproteins from days 74 to 76 of pregnancy in pigs, probably by increasing the uptake of lipoproteins and promoting the use of internalized cholesterol for progesterone synthesis. Prolactin as well as $\mathrm{LH}$ has been shown to stimulate significant increases in progesterone secretion in perifused luteal tissue from pigs, killed on day 80 of pregnancy that had previously (days 67-72) been passively immunized against LH (Szafranska et al., 1992). Thus, our results suggest that prolactin may play a role in the stimulation of progesterone release during this period of pregnancy in pigs.

We observed a tendency for higher concentrations of oestradiol during the entire treatment period in hyperprolactinaemic pigs than in control gilts. Robertson and King (1974) reported that at about days 60-70 of pregnancy in pigs, unconjugated oestrone and oestradiol concentrations begin to increase to the peak values observed before parturition. Moreover, Buttle (1989) reported that in pigs between days 60 and 80 of pregnancy the fetoplacental unit, rather than the ovaries, is the major source of oestrogens. This rise is coincident with the period when it has been suggested that prolactin is the luteotrophin in pigs (Du Mesnil du Buisson and Denamur, 1968, 1969). Hyperprolactinaemia in rats (Koike et al., 1991) suppresses oestrogen-induced LH release by suppressing GnRH release from the hypothalamus. In contrast, administration of oestradiol possibly affects dopamine, probably through the tuberohypophysial system by increasing turnover and synthesis of dopamine in the median eminence, thus stimulating dopamine release into portal blood (Ben-Jonathan et al., 1989). Oestradiol may act directly on prolactin-releasing factor(s) from the intermediate lobe (Laudon et al., 1990), or indirectly, via hypothalamic neurones terminating in the posterior pituitary (Murai and Ben-Jonathan, 1990). Furthermore, the oestrogenic factor may be 'an enhancer' for luteotrophic function.

In conclusion, prolactin is more involved in the functions of the luteotropic complex (via a specific mechanism of 'substitutory compensation') during the second half of pregnancy in pigs than has been previously reported, but, presently, this mechanism remains unclear.

Published with the approval of the Director of the Agricultural Experiment Station as Journal Article No. 2100. Part of the results were presented at the 24th Annual Meeting of the Society for the Study of Reproduction, University of British Columbia, Canada. The authors are grateful to K. Kochman (Jablonna, Poland) for provision of porcine prolactin and L. E. Reichert, Jr, (Albany, USA) for porcine LH. The authors thank R. Zimprich for the provision of the animals, T. Johnson and T. Skunberg of the Small Animal Research Center for their care of animals and help during the experiments and D. Zaeske from Meats Laboratory for slaughter of the animals. Special thanks are given to $\mathrm{R}$. Weigl for his continuous assistance and patient guidance throughout the study.

\section{References}

Ben-Jonathan N, Abrogast LA and Hyde JF (1989) Neuroendocrine regulation of prolactin release Progress in Neurobiology 33 399-447

Benker G, Jaspers C, Hausler G and Reinwein D (1990) Control of prolactin secretion Klinische Wochenschrift 68 1157-1167

Buttle HL (1989) On the source of oestradiol secretion at mid-pregnancy in pigs journal of Reproduction and Fertility Abstract Series 3 Abstract, 48

Du Mesnil du Buisson F and Denamur R (1969) Mechanismes du controle de la fonction luteal chez la truie, la brebis et la vache Proceedings of the International Congress of Endocrinology Mexico pp 927-934 Excerpta Medica Foundation, Amsterdam

Dusza L and Kryzmowska H (1979) Plasma prolactin concentrations during the oestrous cycle of sows Journal of Reproduction and Fertility 57 511-514

Grinwich DL, McKibbin PE and Murphy BD (1983) Stimulation of progesterone secretion in the pregnant pig corpus luteum in vitro by prolactin and lipoproteins. In Factors Regulating Ovarian Function pp 123-128 Eds GS Greenwald and PF Terranova. Raven Press, NY

Hotchkiss J, Atkinson LE and Knobil E (1971) Time course of serum estrogen and luteinizing hormone concentration during the menstrual cycle of the rhesus monkey Endocrinology 89 177-183

Imazu Y, Kobayashi K and Shohmori (1989) Comparative study of sulpirine and haloperidol on dopamine turnover in the rat brain Neurochemical Research 14 459-464

Jammes H, Schirar A and Dijane J (1985) Differential patterns in luteal prolactin and LH receptors during pregnancy on sows and ewes Journal of Reproduction and Fertility 73 27-35

Jones PBC, Valk CA and Hsueh AJW (1983) Regulation of progestin biosynthetic enzymes in cultured rat granulosa cells: effects of prolactin, $\beta_{z}$-adrenergic agonist, human chorionic gonadotropin and gonadotropin-releasing-hormone Biology of Reproduction 29 572-585

Koike K, Miyake A, Aono T, Sakumoto T, Ohmichi M, Yamaguchi M and Tanizawa $O$ (1991) Effect of prolactin on the secretion of hypothalamic GnRH and pituitary gonadotropins Hormone Research Supplement 35 5-12

Kraeling RR and Davis BJ (1974) Termination of pregnancy by hypophysectomy in the pig Joumal of Reproduction and Fertility 36 215-217

Laudon M, Grossman DA and Ben-Jonathan N (1990) Prolactin-releasing factor: cellular origin in the intermediate lobe of the pituitary Endocrinology 126 3185-3192

Lejeune $\mathbf{H}$, Bilion P, Charrie A, Fleury MC, Midani MEl, Tourniaire J and Pugeat M (1990) Technology of luteinizing hormone (LH) pulse analysis. In Recent Progress on GnRH and Gonadal Peptides pp 113-128 Eds P Bouchard, F Haour, $P$ Frachimont and B Schatz. Elsevier, Paris

Murai I and Ben-Jonathan N (1990) Acute stimulation of prolactin release by estradiol: mediation by the posterior pituitary Endocrinology 126 3179-3184

Murphy BD and Rajkumar K (1985) Prolactin as a luteotropin Canadian Journal of Physiology and Pharmacology 63 257-264

Nicholics K, Mason AJ, Szony E, Ramachandran J and Seeburg PH (1985) A prolactin-inhibiting factor within the precursor for human gonadotrophinreleasing hormone Nature $316511-517$

Rajkumar K, McKibbin PE, Buhr MM, Grinwich DL and Murphy BD (1984) Differential effects of the luteotropic hormones LH and PRL in control of progesterone output from the pregnant pig corpus luteum in vitro Proceedings of the Tenth International Congress on Animal Reproduction and Artificial Insemination 10 513-516

Rajkumar K, Malinek J and Murphy BD (1985) Effect of lipoproteins on progesterone accumulation by luteal cells from the pregnant pig Steroids $\mathbf{4 5}$ 119-134

Robertson HA and King GJ (1974) Plasma concentrations of progesterone, oestrone, oestradiol-17 $\beta$ and of oestrone sulphate in the pig at implantation, during pregnancy and parturition Journal of Reproduction and Fertitity $\mathbf{4 0}$ 133-141 
Sortino MA and Wise PM (1989) Effect of hyperprolactinemia on LH and prolactin secretion assessed using the reverse hemolytic plaque assay Biology of Reproduction 41 618-625

Szafranska B and Ziecik AJ (1990) Effect of bromocriptine administration on maintenance of late pregnancy in the pig Experimental and Clinical Endocrinology $96321-324$

Szafranska B, Grazul-Bilska AT and Przala J (1992) Effect of LH and prolactin on steroid secretion by perifused luteal tissue from pregnant gilts with immunoneutralization of LH Archiva Veterinaria Poland 32 7-15

Vacher P, Mariot P, Dufy-Barbe L, Nikolics K and Seeburg PH (1991) The gonadotropin-releasing hormone associated peptide reduces calcium entry in prolactin-secreting cells Endocrinology 128 285-294
Wiest WG, Kidwell WR and Balogh K, Jr (1968) Progesterone catabolism in the rat ovary: a regulatory mechanism for progestational potency during pregnancy Endocrinology 82 844-859

Yangfan Li, Molina JR, Klindt J, Bolt DJ and Anderson LL (1989) Prolactin maintains relaxin and progesterone secretion by aging corpora lutea after hypophysial stalk transection or hypophysectomy in the pig Endocrinology 124 1294-1304

Ziecik A, Goralska M, Krzymowski T and Pogorzelski K (1978) Isolation and purification of porcine LH for radioimmunoassay Bulletin Polish Academy of Science Class II Series Biology 26 739-744 